\title{
SUSTAINABLE DEVELOPMENT ASSESSMENT IN LATVIA: THE EXAMPLE OF LATGALE REGION
}

\author{
DMITRIJS OLEEHNOVIČS \\ The Department of History, Daugavpils University, Latvia
}

https://doi.org/10.35945/gb.2017.03.004

INTA OSTROVSKA

The Institute of Humanities and Social Sciences, Daugavpils University, Latvia

VIKTORIJA ŠIPILOVA

The Institute of Humanities and Social Sciences, Daugavpils University, Latvia

ELITA JERMOLAJEVA

Latvian Academy of Agricultural and Forestry Sciences, Latvia

\author{
LUDMILA ALEKSEJEVA
}

The Department of Economics and Sociology, Daugavpils University, Latvia

KEYWORDS: SUSTAINABLE DEVELOPMENT, SMART SPECIALIZATION, RURAL AREAS, LATGALE REGION (LATVIA)

The European Commission (2012) indicates that wise specialization is essential not only for sustainable development of individual states, but it is also fundamental in the development of individual regions. Particular emphasis is placed on the importance of using scientific approaches in the development of the concept of regional development. At the same time, it is necessary to re-assess the traditional methods of reforming regional policies; nowadays the transition to interdisciplinarity is obvious, for example, bio-economics, when regions seeking new ways of strategic development can strive for sustainable production of added value, supplementing and improving their activities in traditional spheres (for example, forestry and agriculture, fisheries, etc.). Scientists and politicians particularly emphasize that the analysis of regional potential for sustainable development should begin with the assessment of environmental, economic, social and managerial aspects (EK, 2012, e.g., Kirk et al., 2010).

The shift of modern regional development paradigm has facilitated the awareness of the importance of potential and endogenous factors of every region (e.g., Vanthillo, Verhetsel, 2012). However, the question about the pronouncedly different possibilities of various territories to safeguard sustainable development has become acute. Solving the above-mentioned problem is possible only by using the approach of comparative regional advantages, and probably, it is the right approach. Such an approach requires implementing the concept of smart specialization (e.g., Naldi et al., 2015; Koumparou, 2013). In fact, this means the development and implementation of wise development strategies that are based on assessing the potential of the region(s) and determining the priorities for their development. It is a particular challenge for rural areas that are often characterized by small numbers of inhabitants, low incomes, low level of education and a considerable distance from "knowledge" centres (e.g., Steiner, Mossbock, 2014).

The present study offers an example of a methodological solution for the assessment of sustainable socio-economic development in rural areas based on the concept of smart specialization that has been developed within the framework of the Latvian National Research Programme EKOSOC-LV (see http://www.lza.Iv/index.php?option=com_content $\&$ task=vie w\&id=2312\& Itemid=443).

The notion of sustainable development has been associated with a theoretical attempt of balanced research into environmental, humanitarian, social and economic needs of regional development in the conditions of dynamic world. At the same time, it is noteworthy that this concept is still being developed, and, for example, the Scopus database contains only a limited number of publications that are directly focused on issues of sustainable socio-economic regional development. Besides, research results mainly reflect wise approaches to specialization by means of the implementation of balanced regional development policies, thus creating a kind of bridge for the transition from the traditional economy to the knowledge economy. In this respect, it is important to understand that the creation, dissemination and application of the accumulated theoretical concepts require the existence of the so-called innovative ecosystem, in which knowledge will contribute to flourishing of innovative entrepreneurship (e.g., Romano et al., 2013).

Notwithstanding its popularity in various theories, the term smart development has not been precisely defined and its interpretations may differ within different scientific disciplines (Sinkiene et al., 2014). In economic literature, smart development is related to the fundamentals of sustainable development (Naldi et al., 2015); and in the USA, smart development is understood as sustainable development (e.g., Krueger, 2010).

On the other hand, there is also a critical point of view regarding the development of strategies for smart growth and regional development, which emphasizes that the process of development itself does not oblige the strategy execution (for example, Reimeris, 2016). However, Reimeris (2016) also recognizes that smart development strategies (e.g., RIS3) provide a mechanism for advancing change and developing multi-vector concepts for regional development. In addition, well-elaborated regional development policy helps to clearly 
identify priorities, evaluate available resources and possible obstacles for realizing regional potential during the implementation of the aims set (e.g., Šipilova, 2014).

There is no single method that would be appropriate in all the cases because each area has its own unique cultural, historical, socio-economic, political and logistic peculiarities and, which is no less important, needs. However, when developing the strategy, there are a number of common aspects, which gives the possibility for a universal interpolation of theoretical approaches and practical calculations.

The methodological solution. The goal of the national research programme EKOSOC-LV is to develop an instrument that would enable specialists to work out scientifically grounded propositions for the assurance of balanced and sustainable development of rural areas in Latvia (Latvijas Zinātnu Akadēmija, 2014). One of the greatest challenges is the methodological solution that would enable an objective assessment of both the current situation and the development potential and priority directions taking into account the concept of smart specialization in ensuring sustainable development (e.g., Zvirbule A. Et al., 2016).

Methodological challenges related to the implementation of smart regional specialization are topical also in Lithuania (e.g., Poliakaite et al., 2015). Lithuanian colleagues agree that a holistic approach and the promotion of innovation in any field of activity form the path to successful implementation of smart specialization strategy (Poliakaite et al., 2015). Similar conclusions have been made by the authors of the present article (Ostrovska et al., 2016), when analysing the peculiarities of the contemporary regional development paradigms as described in research literature. The authors (Ostrovska et al., 2016) have concluded that the cooperation among the parties involved in the process of regional development is an essential prerequisite for smart development, while the holistic approach, which combines environment, society, economy and management for meeting the unique regional needs, is the basis for ensuring sustainable development.

In the framework of the present study, the authors have carried out three successive steps in order to assess sustainable development by using the concept of smart specialization:

1) characterization of the development of rural areas;

2) the quantitative description of the peculiarities of regional development;

3) the qualitative characterization of the development by involving experts representing national, municipal and business structures.

Such an approach allows for understanding of the peculiarities of the current development from the point of view of sustainability by answering two questions - What is the situation? and What should it be?; and comparing the answers.

The quantitative assessment. Before carrying out the assessment of sustainable development, it is essential to understand the typology of rural areas and their features. In the development of the typology of rural areas, the EDORA Cube principles were partially used according to Copus and Noguera (2010). Rural areas were divided according to their level of socio-economic development, as well as the number of population, which allowed for revising the stereotypes concerning rural areas. The typology development was based on the data concerning the dynamics of economically active statistical units of the market sector and sole proprietorships (the rate of development) (RDIM, 2015) and the index of territorial development (level of development) (SRDA, 2010, $2011,2012)$. Such a division of territories provided the information about the current capacity of rural areas. The answer to the question To what extent is this developmental capacity echoed in smart rural development? was sought for by developing Smart Development Index.

Smart Development Index as a quantitative indicator of regional development is an integrated index that includes four dimensions - Resources, Population, Economy and Management. Scholars emphasize that in order to carry out an effective assessment of the current situation it is necessary to consider the integrated index that allows for the assessment of common achievements in a particular field (e.g., Marsal-Llacuna et al., 2015) or evaluate the uniqueness of the area (e.g., Gedminaite-Raudone, 2014).

It should be noted that during the development of the index, the importance of each dimension in the index was also considered - Resources 0.19, Population 0.26, Economy 0.44, and Management 0.11 . The calculated values testify to the fact that Economy and Population have the largest weight in the process of research on smart development, while the weight of Resources and Management is considerably smaller. Smart Development Index adopts both positive and negative values, which are respectively indicative of the level and the quality of smart development of an area (e.g., Zvirbule A. et al., 2016).

The qualitative assessment. Finally, in the course of the study, the triple-helix model was actualized. This model is essential for the assurance of awareness of challenges related to sustainable development and shows the preferred model of cooperation among experts involved in the development of the programme. The method used to carry out the experts' survey was the Analytic Hierarchy Process (AHP). The experts' answers provided the information that allows for the comparison of the current situation with the desired one, thus revealing both strengths and weaknesses of smart development.

Research results. The greatest challenge in Latgale region is related to the loss of human capital and the sluggish development trends in entrepreneurship (e.g., Latgales plānošanas reǵions, 2010a, 2010b). The programme and the strategy of the region's development (e.g., Latgales plānošanas reǵions, 2010a, 2010b) envisage a set of measures aimed at mitigating the negative trends. These measures are based on raising efficiency of the use of local resources, on activating the cooperation between the parties involved in the process of development, and in strengthening the business sector (e.g., Latgales plānošanas reǵions, 2010a, 2010b).

In an economic perspective, a significant contribution to the development of Latgale region is ensured by the relatively successful operation of the high technology sector of manufacturing, and the use of rich natural resources (e.g., Latgales plānošanas reǵions, 2010a, 2010b). However, it should be noted that the potential of rich natural resources of Latgale 
region, due to the low economic activity, is mostly used with low added value (e.g., Latgales plānošanas reǵions, 2010a, $2010 b)$. The low growth of labour productivity is obvious not only in Latgale region and it is one of the main reasons for overall worsening of external competitiveness of Latvian economy (e.g., Baldi, Šipilova, 2014).

The analysis performed allows identifying the following trends:

1) the areas with a relatively high level of development show stagnation;

2) some of the less developed areas are able to increase their pace of development.

On the one hand, the identified trends may be indicative of certain "confusion" of the districts about further realization of their potential due to the lack of sufficiently strong impulses. On the other hand, it is positive that the relatively less developed regions are accelerating their development.

All in all, the rural areas of Latgale region demonstrate a striking dominance of slow development. According to the paradigm of contemporary regional development, one of the most essential driving forces of development is a human being, therefore it is essential to understand the "stagnating" and "fast growing" rural population.

Peculiarities of the development of Latgale region: evaluation of sustainability by using the concept of smart specialization. The improvement of a region's welfare in the framework of a new paradigm of regional development should be linked to strengthening the competitiveness of territories by making use of their potential (e.g., ESPON, University Rovira i Virgil, 2012), i.e. resources, social capital, technologies of efficient management and institutional capacity. Paying special attention to the respective aspects of regional development is a major challenge for every region. The development of an integrated indicator (Smart Development Index), which includes all the dimensions necessary for regional development (Resources, Population, Economy and Management) allows for identifying the developmental trends in Latgale anew.

The median values of the Smart Development Index demonstrate that the level of smart development in Latgale region is comparable to the performance of other regions. For instance, both Kurzeme and Zemgale regions demonstrate the median values of the Smart Development Index that are close to those observed in Latgale region. In addition, the lowest index value $(-10.008)$ has been encountered in Skrunda district (Kurzeme), rather than in Latgale region, where the lowest index value is -5.113 .

The maximum values of the Smart Development Index also manifest that strikingly unfavourable development in Latgale region is not being observed. The maximum value of the index 7.386 attained in llūkste district is not far from the maximum value of the index reached in Kurzeme, which is 10.554. In addition, it may be concluded that smart development in Latgale region proceeds smoother than in other regions because the difference between the maximum and the minimum values of the index is smaller than in other regions.

However, in general, the values of the Smart Development Index in areas of Latgale region are relatively low. The calculations of the median values manifest that in half of the districts of Latgale region the Smart Development Index is less than 0.43 , and this value is about 2.5 times lower than the index mean value of 1.074 . The median value in Latgale region testifies to the fact that in most of the region's rural areas, smart development is markedly delayed in comparison with other regions of Latvia. For example, the highest median value of 4.03 is observed in Vidzeme region and this indicator is nine times higher than in the region of Latgale. Furthermore, in Vidzeme region the difference between the median and the average values of the index is very small.

The qualitative assessment of smart development: triple-helix model. In April 2016, within the framework of the National Research Programme EKOSOC-LV, a scientific and practical seminar "Possibilities of smart development in Latvian rural areas and regions" was organized, in which particular attention was paid to the region of Latgale. During the seminar, a survey of experts representing the public sector, entrepreneurship and research was organized. The survey was carried out by means of the AHP method. The main results of the survey are presented in this part of the paper and help to understand the analysis of the quantitative results. The experts were asked about four dimensions of smart development and their importance in the development of Latgale region, as well as about the influence of the population, the municipalities, the state and the EU, thus determining the prevailing impact factors, i.e. the population's initiative and activity or the institutional environment.

According to the experts, the major role in ensuring smart development belongs to the dimensions Population (0.37) and Economy (0.29). The dimensions Management (0.17) and Resources (0.16), according to the experts, are less important in the process of ensuring smart regional development. The combination of the quantitatively determined trends of smart development in Latgale region and the experts' evaluation (the qualitative assessment) of the significance of the dimensions allows for the description of a complex assessment of trends in the regional development.

Conclusions. The National Research Programme EKOSOC-LV being in the $3^{\text {rd }}$ stage of its implementation, the researchers have conducted the quantitative and qualitative assessment of scenarios for smart development in rural areas of Latgale region. The results obtained have both scientific and practical significance in promoting sustainable development in rural areas. First, the results of the study propose a possible methodological solution for the assessment of sustainable development by using the concept smart specialization. Second, the acquired research experience can be used for solving practical tasks at the level of districts of the region of Latgale.

\section{To be continued}

The study has been supported by the National Research Programme 5.2. "Economic transformation, smart growth, governance and legal framework for sustainable development of the state and society - a new approach to the creation of a sustainable learning community" (EKOSOC-LV). 


\section{REFERENCES:}

1. Adomßent, M. (2013). Exploring universities' transformative potential for sustainability-bound learning in changing landscapes of knowledge communication. Journal of Cleaner Production, Volume 49, June 2013, 11-24. doi: http://doi. org/10.1016/j.jclepro.2012.08.021

2. Baldi, G., Šipilova, V. (2014). Economic structure, welfare, and the real exchange rate. The International Journal of Interdisciplinary Social and Community Studies, Volume 8, Issue 2, 13-22.

3. Copus, A. \& Noguera, J. (2010). A Typology of Intermediate and Predominantly Rural NUTS 3 Regions. The ESPON 2013 Programme Applied Research Project 2013/1/2. EDORA (European Development Opportunities for Rural Areas). Version 4, 17th September 2010. Retrieved August 10, 2015, from http://www.nordregio.se/Global/Research/EDORA/EDORA_2.22.pdf

4. Eiropas Savienības Padome. (2006). ES ilgtspējīgas attistības stratēǵija. Retrieved April 13, 2016, from www.varam.gov. Iv/.../ilgtspejiga...//ST10917-RE03[1].LV06.DOC.doc

5. ESPON, University Rovira i Virgil. (2012). ATTREG - The Attractiveness of European regions and cities for residents and visitors. Retrieved August 10, 2015, from https://www.espon.eu/export/sites/default/Documents/Projects/AppliedResearch/ATTREG/FR_20130123/ATTREG_FR.pdf

6. ESPON. (2013). Programme Applied Research Project 2013/1/2. EDORA (European Development Opportunities for Rural Areas). Version 4, 17th September 2010. Retrieved August 10, 2015, from http://www.nordregio.se/Global/Research/ EDORA/EDORA_2.22.pdf

7. European Commission. (2012). Connecting Smart and Sustainable Growth through Smart Specialisation. A practical guide for ERDF managing authorities. Retrieved April 13, 2016, from http://ec.europa.eu/regional_policy/sources/docgener/ presenta/green_growth/greengrowth.pdf doi:10.2776/70221

8. European Union. Directorate General for Regional Policy. (2011). Cities of tomorrow - Challenges, visions, ways forward. Retrieved April 13, 2016, from http://ec.europa.eu/regional_policy/sources/docgener/studies/pdf/citiesoftomorrow/citiesoftomorrow_final.pdf doi:10.2776/41803

9. Gedminaite-Raudone, Z. (2014). Economic assessment of uniqueness of the regions in the context of the European Union. Procedia - Social and Behavioral Sciences, 110 (2014), 259 - 266. doi: https://doi.org/10.1016/j.sbspro.2013.12.869

10. Huggins, R., Izushi, H., Prokop, D., \& Thompson, P. (2014). Regional evolution and waves of growth: A knowledge-based perspective. Expert Systems with Applications, 41 (2014), 5573-5586. doi: http://doi.org/10.1016/j.eswa.2014.02.008

11. Kirk, K., Tableporter, J., Senn, A., Day, J., Cao, J., Fan, Y., Slotterback, C.S., Goetz, E., \& McGinnis, L. (2010). Framework for Measuring Sustainable Regional Development for the Twin Cities Region. Final Report. Published by Center for Transportation Studies University of Minnesota. January 2010. Retrieved April 13, 2016, from www.cts.umn.edu/Publications/ ResearchReports/pdfdownload.pl?id=1328

12. Koumparou, D. (2013). The Role of Natural Resources and the Social Capital in EU's Growth Strategy - Europe 2020. Edited by: Lekkas, TD. Proceedings of the 13th International Conference on Environmental Science and Technology. Retrieved March 10, 2017, from http://apps.webofknowledge.com/full_record.do?product=WOS\&search_mode=GeneralSearch\&qid $=4 \& S I D=V 1$ Xgpu7jfuCitdgmTZD\&page $=1 \&$ doc $=1$

13. Krueger, R. (2010). Smart Growth and Its Discontents: An examination of American and European Approaches to Local and Regional Sustainable Development. Doc. Anàl. Geogr., 2010, Vol. 56/3, 409-433.

14. Latgales plānošanas regions. (2010a). Latgales attistibas stratēǵija 2030. Retrieved October 17, 2016, from http://www. latgale.Iv/lv/padome/planosana

15. Latgales plānošanas regions. (2010b). Latgales plānošanas reǵiona attīstïbas programma 2010-2017. Esošās situācijas analïze. Retrieved October 17, 2016, from http://www.latgale.lv/lv/padome/planosana

16. Latvijas Zinātṇu Akadēmija. (2014). Valsts pētijumu programma 5.2.1. "Tautsaimniecības transformāciju, gudra izaugsme, pārvaldība un tiesiskais ietvars valsts un sabiedrības ilgtspējīgai attīstïbai - jaunas pieejas ilgtspejjīgas zināšanu sabiedrības veidošanai (EKOSOC-LV)". Retrieved April 13, 2016, from http://www.lza.lv/index.php?option=com_content \&task=view\&id=2312\&ltemid $=443$

17. Lindqvist, M., Smed Olsen, L., \& Perjo och Haukur Claessen, L. (2013). Implementing the Concept of Smart Specialisation in the Nordic Countries an Exploratory Desk Study. Nordregio Working Paper, 2013:1. Retrieved April 13, 2016, from https://www.diva-portal.org/smash/get/diva2:700298/FULLTEXT01.pdf

18. Marsal-Llacuna, M.-L., Colomer-Llinàs, J., \& Meléndez-Frigola, J. (2015). Lessons in urban monitoring taken from sustainable and livable cities to better address the Smart Cities initiative. Technological Forecasting and Social Change, Volume 90, Issue PB, January 01, 2015, 611-622. doi: http://doi.org/10.1016/j.techfore.2014.01.012

19. Melbarde, V., \& Ore, M. (2016). Influencing Factors of Rural Areas Development Vidzeme Region Case Analysis. Proceedings of the New Challenges of Economic and Business Development - 2016, 484-495.

20. Muscio, A., Rivera León, L., \& Reid, A. (2013). Can smart specialisation help overcome the regional innovation paradox. UCL-SSEES, LONDON, 26/06/2013. Retrieved April 13, 2016, from https://www.ucl.ac.uk/ssees/docs/economics-and-business-seminars-documents/smart-specialisation-regional-innovation-paradox.pdf

21. Naldi, L., Nilsson, P., Westlund, H., \& Wixe, S. (2015). What is smart rural development? Journal of Rural Studies, Volume 40, August 01, 2015, 90-101. doi: http://doi.org/10.1016/j.jrurstud.2015.06.006 
22. OECD. (2013). Innovation-driven Growth in Regions: The Role of Smart Specialisation. Preliminary Version. Retrieved April 13, 2016, from https://www.oecd.org/innovation/inno/smart-specialisation.pdf

23. Ostrovska, I., Šipilova, V., Aleksejeva, L., Jermolajeva, E., \& Oḷehnovičs, D. (2016). Mūsdienu reǵionālās attīstības paradigmas īpatnības: Ārvalstu zinātniskās pieredzes apkopojums. Proceedings of the International Scientific Conferences of Faculty of Social Sciences of Daugavpils University. The materials of the International Scientific Conference "Social Sciences for Regional Development 2015" (16th-17th October 2015). Part I. Issues of Sociology, 55-74.

24. Paliokaite, A., Martinaitis, Ž., \& Reimeris, R. (2015). Foresight methods for smart specialization strategy development in Lithuania. Technological Forecasting and Social Change, 101 (2015), 185-199. doi: http://doi.org/10.1016/j.techfore.2015.04.008

25. Regional development indicators module of Spatial Development Planning Information System (RDIM). (2015). Data Tables. Retrieved August 10, 2015, from http://www.raim.gov.lv

26. Reimeris, R. (2016). New rules, same game: the case of Lithuanian Smart specialization. European Planning Studies, Volume 24, Issue 8, 2 August 2016, 1561-1583. doi: http://dx.doi.org/10.1080/09654313.2016.1179722

27. Romano, A., Del Vecchio, P., Secundo, G., Brunetti, F. (2013). A Framework for Policies implementing the Smart Specialization Strategy: the Sustainable Innovation Ecosystem. Proceedings of the IFKAD 2013: 8th International Forum on Knowledge Asset Dynamics: Smart Growth: Organizations, Cities and Communities. Edited by: Schiuma G.; Spender JC.; Pulic A., 1608-1620.

28. Sinkiene, J., Grumadaite, K., \& Liugailaite-Radzvickiene, L. (2014) Diversity of Theoretical Approaches to the Concept of Smart City. Proceedings of the 8th International Scientific Conference Business and Management 2014, 933-940. DOI: 10.3846/bm.2014.112

29. Šipilova, V. (2014) Regional policy as indicator of readiness for structural change: the case of Latvia. Mediterranean Journal of Social Sciences, Vol.5, No.13, June 2014, 391-397. DOI: 10.5901/mjss.2014.v5n13p391

30. Šipilova, V. (2015) When regional growth does not benefit from high-tech specialization? Explaining the experience of Latvian regions. Procedia Economics and Finance, 30(2015), 863-875. doi: https://doi.org/10.1016/S2212-5671(15)01336-2

31. State Regional Development Agency (SRDA). (2010). Development of Regions in Latvia 2009. Annex. 4.: Development Indexes of the Planning Regions and Administrative Territories Existing since July 1, 2009. Available: http://www.vraa.gov. Iv/uploads/Development of Regions 2009.pdf

32. State Regional Development Agency (SRDA). (2011). Development of Regions in Latvia 2010. Annex. 2.: Planning Region, Republican City and Novads Territory Development Indexes. Retrieved August 10, 2015, from http://www.vraa.gov.lv/uploads/ Development_of_Regions_in_Latvia_2010_web_ENG.pdf

33. State Regional Development Agency (SRDA). (2012). Development of Regions in Latvia 2011. Annex. 2.: Territorial Development Indices of Planning Regions, Cities and Municipalities. Retrieved August 10, 2015, from http://www.vraa.gov.lv/ uploads/regionu\%20parskats/Regionu\%20attistiba\%20Latvija\%202011\%20ENG_Q_ia\%20kartes\%20horizontali.pdf

34. Steiner, M., \& Mossbock, J. (2014). How "smart" are rural areas? A case study approach. RSA Winter Conference 2014, November 27-28 2014, London, UK. Retrieved July 20, 2016, from http://www.regionalstudies.org/uploads/funding/conferences/presentations/Winter_2014_Presentations_/Michael_Steiner_and_Johannes_Mossb\%C3\%B6ck.pdf

35. Sustainable Cities, Canadian International Development Agency. (2012). Indicators for Sustainability: How cities are monitoring and evaluating their success. Retrieved April 13, 2016, from: http://www.mayorsinnovation.org/images/uploads/ pdf/2_-_International_Case_Studies.pdf

36. Vanthillo T., \& Verhetsel A. (2012). Paradigm change in regional policy: towards smart specialisation? Lessons from Flanders (Belgium). Belgeo, 1-2 (2012), Inaugural Issue. Retrieved April 13, 2016, from: https://belgeo.revues.org/pdf/7083 DOI: $10.4000 /$ belgeo.7083

37. Zvirbule A., Rivza B. and Bulderberga Z. (2016) Determinant Factors for the Formation and Development of a Smart Territory. Springer Nature Singapore Pte Ltd. 2017 E. Lau et al. (eds.), Selected Papers from the Asia-Pacific Conference on Economics \& Finance (APEF 2016), p. 53 - 63, DOI 10.1007/978-981-10-3566-1_5 


\section{SUSTAINABLE DEVELOPMENT ASSESSMENT IN LATVIA: THE EXAMPLE OF LATGALE REGION}

\section{DMITRIJS OḶEHNOVIČS}

The Department of History, Daugavpils University, Latvia

INTA OSTROVSKA

The Institute of Humanities and Social Sciences, Daugavpils University, Latvia

VIKTORIJA ŠIPILOVA

The Institute of Humanities and Social Sciences, Daugavpils University, Latvia

ELITA JERMOLAJEVA

Latvian Academy of Agricultural and Forestry Sciences, Latvia

LUDMILA ALEKSEJEVA

The Department of Economics and Sociology, Daugavpils University, Latvia

KEYWORDS: SUSTAINABLE DEVELOPMENT, SMART SPECIALIZATION, RURAL AREAS, LATGALE REGION (LATVIA)

\section{SUMMARY}

Nowadays, much interest is devoted to the use of innovative (or wise) methods in assessing regional development. Rural areas have particular importance in ensuring sustainable development of any state; moreover, smart approaches to the assessment of regional development potential help determining common trends in the socio-economic development of the state as a whole. The present study shows the possibility of an integrated use of quantitative and qualitative methods in the assessment of the sustainable development of Latgale region (Eastern Latvia). The assessment was carried out within the framework of the project 5.2. of the national research program EKOSOC-LV. The quantitative assessment was based on scientific and practical experience taking into consideration the peculiarities of the development of Latvian regions and districts and resulted in the establishment of an integrated index (Smart Development Index), which comprises four dimensions - Resources, Population, Economy, and Management. The qualitative assessment was based on the viewpoints concerning the cornerstones of smart specialization and the factors influencing it expressed by experts representing the state administration, business and scientific environment. Expert opinions were collected by using the AHP method. The results of the research can contribute to the development of a scientifically grounded state and regional policy that reveals the full potential of smart development of rural areas, taking into account the rate of the regional socio-economic development. The case and the methodology of the present study can also be interpolated to other regions experiencing the need for creating an integrated, scientifically grounded, balanced and sustainable policy of regional development.

The research is supported by the State Research programme 5.2. "Economy transformation, smart development, management and legal framework for the sustainable development of the state and the society - new approaches in the development of sustainable knowledge society (EKOSOC-LV)" 